\title{
Synthesis of New Sugar-Based Surfactants and Evaluation of their Haemolytic Activities
}

Kristina Neimert-Andersson, Sven Sauer, Olaf Panknin, Tessie Borg, Erik Söderlind, and Peter Somfai ${ }^{*}$

KTH Chemical Science and Engineering, Organic Chemistry, S-100 44 Stockholm, Sweden.

AstraZeneca R\&D Mölndal S-431 83 Mölndal, Sweden.

somfai@kth.se

\section{SUPPORTING INFORMATION}

Experimentals for compounds 7, 8, 12, 13, 2-4 2

Determination of CMC and haemolytic activity 6

${ }^{1} \mathrm{H}$ NMR for compound 9

${ }^{13} \mathrm{C}$ NMR for compound 9

${ }^{1} \mathrm{H}$ NMR for compound $\mathbf{1 0} \quad 10$

${ }^{13} \mathrm{C}$ NMR for compound $\mathbf{1 0} \quad 11$

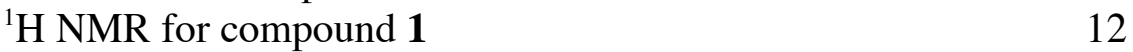

${ }^{13} \mathrm{C}$ NMR for compound $\mathbf{1} 13$

${ }^{1} \mathrm{H}$ NMR for compound $\mathbf{1 1} \quad 14$

${ }^{13} \mathrm{C}$ NMR for compound 11

${ }^{1} \mathrm{H}$ NMR for compound 2

$\begin{array}{ll}{ }^{13} \mathrm{C} \text { NMR for compound } 2 & 17\end{array}$

${ }^{1} \mathrm{H}$ NMR for compound $\mathbf{1 2} 18$

${ }^{13} \mathrm{C}$ NMR for compound 12 19

${ }^{1} \mathrm{H}$ NMR for compound $\mathbf{3} \quad 20$

${ }^{13} \mathrm{C}$ NMR for compound $\mathbf{3}$

${ }^{1} \mathrm{H}$ NMR for compound $\mathbf{1 3} \quad 22$

${ }^{13} \mathrm{C}$ NMR for compound $\mathbf{1 3} \quad 23$

${ }^{1} \mathrm{H}$ NMR for compound 4

${ }^{13} \mathrm{C}$ NMR for compound 4 
Methyl-2,3,4-tri- $\boldsymbol{O}$-benzyl-6-amino-6-deoxy- $\boldsymbol{\alpha - D}$-glucopyranoside $\quad(7)$. Mesylate $\mathbf{6}^{17} \quad(0.5 \mathrm{~g}$, $0.95 \mathrm{mmol})$ was dissolved in a mixture of THF $(4 \mathrm{~mL})$ and $\mathrm{NH}_{4} \mathrm{OH}(25 \%$ aq., $10 \mathrm{~mL})$ in a sealed tube. The reaction mixture was heated to $100{ }^{\circ} \mathrm{C}$ for 2 days, then allowed to cool to rt. The mixture was extracted three times with $\mathrm{Et}_{2} \mathrm{O}$, dried $\left(\mathrm{MgSO}_{4}\right)$, and concentrated to give 7 in $86 \%$ yield $(0.39 \mathrm{~g}, 0.82 \mathrm{mmol})$. Analytical data were in accordance with those reported previously. ${ }^{17}$

Methyl-2,3,4-tri- $\boldsymbol{O}$-benzyl-6-oxo- $\boldsymbol{\alpha}$-D-glucopyranoside (8). DMSO (2.4 mL, $37.3 \mathrm{mmol})$ was dissolved in $\mathrm{CH}_{2} \mathrm{Cl}_{2}(10 \mathrm{~mL})$, and cooled to $-78{ }^{\circ} \mathrm{C}$ before addition of oxalyl chloride $(1.47 \mathrm{~mL}$, $18.6 \mathrm{mmol})$. The solution was stirred for $20 \mathrm{~min}$ at $-78{ }^{\circ} \mathrm{C}$, and then alcohol $\mathbf{5}^{16}(5.1 \mathrm{~g}, 11.0 \mathrm{mmol})$ dissolved in $\mathrm{CH}_{2} \mathrm{Cl}_{2}(10 \mathrm{~mL})$ was added. After stirring for additionally $1 \mathrm{~h}$ at $-78{ }^{\circ} \mathrm{C}, \mathrm{Et}_{3} \mathrm{~N}(8 \mathrm{~mL})$ was added and the mixture stirred for $20 \mathrm{~min}$ at $-78{ }^{\circ} \mathrm{C}$, before it was allowed to reach $\mathrm{rt}$. The reaction was quenched by the addition of $\mathrm{H}_{2} \mathrm{O}$, the phases were separated and the organic layer washed with brine. Drying $\left(\mathrm{MgSO}_{4}\right)$ and evaporation of the solvents gave $4.0 \mathrm{~g}$ of $\mathbf{8}$. This material was taken to the next step without further purification due to the instability of the compound: ${ }^{1} \mathrm{H} \mathrm{NMR}\left(400 \mathrm{MHz}, \mathrm{CDCl}_{3}\right): \delta 9.65$ (s, 1H), 7.40-7.26 (m, 15H), $5.00(\mathrm{~d}, J=10.8 \mathrm{~Hz}, 1 \mathrm{H}), 4.90-4.76(\mathrm{~m}, 3 \mathrm{H}), 4.67-4.59$ (m, 3H), 4.17 (d, $J=10.3$ $\mathrm{Hz}, 1 \mathrm{H}), 4.08$ (dd, $J=9.6,8.8 \mathrm{~Hz}, 1 \mathrm{H}), 3.57$ (dd, $J=10.3,8.8 \mathrm{~Hz}, 1 \mathrm{H}), 3.50$ (dd, $J=9.6,3.4 \mathrm{~Hz}, 1 \mathrm{H}), 3.38$ (s, $3 \mathrm{H}) ;{ }^{13} \mathrm{C}$ NMR $\left(100 \mathrm{MHz}, \mathrm{CDCl}_{3}\right): \delta 197.5,138.4,137.8,137.4,128.52,128.49,128.45,128.2,128.10$, $128.08,128.05,128.0,127.8,98.4,81.7,79.2,77.8,75.9,75.1,74.2,73.6,55.8$.

General procedure for the synthesis of 12 and 13. Synthesis of (12R)-12-Hexanoyloxystearylbis(methyl-2,3,4-tri-O-benzyl-6-deoxy- $\alpha$-D-glucopyranoside) amine (12). Preparation of acid chloride: To a solution of hexanoic acid $(501 \mu \mathrm{L}, 4.00 \mathrm{mmol})$ in $\operatorname{dry} \mathrm{CH}_{2} \mathrm{Cl}_{2}(8 \mathrm{~mL})$ were added $\mathrm{DMF}$ (1 drop) and oxalyl chloride $(1.05 \mathrm{~mL}, 12.0 \mathrm{mmol})$ dropwise at $\mathrm{rt}$. The reaction mixture was stirred at $\mathrm{rt}$ until the cease of gas evolution and for additionally $1 \mathrm{~h}$ (in total $2 \mathrm{~h}$ ). The mixture was concentrated in vacuo, $\mathrm{CH}_{2} \mathrm{Cl}_{2}(5 \mathrm{~mL})$ was added and it was concentrated again. After repeating the addition and evaporation once more, $\mathrm{CH}_{2} \mathrm{Cl}_{2}(40 \mathrm{~mL})$ was added and this solution was used in the acylation reaction $(0.1 \mathrm{M})$

Acylation: To a cooled solution of alcohol $10(150 \mathrm{mg}, 126 \mu \mathrm{mol})$ in dry $\mathrm{CH}_{2} \mathrm{Cl}_{2}(2.5 \mathrm{~mL})$ were added successively pyridine $(204 \mu \mathrm{L}, 2.52 \mathrm{mmol})$ and hexanoyl chloride $\left(12.6 \mathrm{~mL}\right.$ of a $0.1 \mathrm{M}$ in $\mathrm{CH}_{2} \mathrm{Cl}_{2}$, 
$1.26 \mathrm{mmol})$. After stirring for $5.5 \mathrm{~h}$ at $\mathrm{rt}$ the mixture was quenched with $\mathrm{HCl}(0.1 \mathrm{M})$. The phases were separated and the aqueous phase was extracted with $\mathrm{CH}_{2} \mathrm{Cl}_{2}(2 \times 7 \mathrm{~mL})$. The combined organic phases were washed with $\mathrm{NaHCO}_{3}$ (sat., $\left.2 \times 10 \mathrm{~mL}\right), \mathrm{H}_{2} \mathrm{O}$ and brine, dried $\left(\mathrm{MgSO}_{4}\right)$ and concentrated in vacuo. The resulting yellowish oil was subjected to flash chromatography (pentane:EtOAc 4:1 $\rightarrow 3: 1 \rightarrow 2: 1$ ) to give $\mathbf{1 2}$ as a bright yellowish syrup in $94 \%$ yield $(152 \mathrm{mg}, 0.118 \mathrm{mmol}):{ }^{1} \mathrm{H} \mathrm{NMR}\left(\mathrm{CDCl}_{3}, 500 \mathrm{MHz}\right): \delta$ 7.36-7.20 (m, 30H), 5.01-4.55 (m, 13H), 4.47 (d, J=3.4 Hz, 1H), 4.45 (d, J=3.6 Hz, 1H), 4.02-3.99 (m, 1H), 3.96 (t, $J=9.2 \mathrm{~Hz}, 1 \mathrm{H}), 3.95(\mathrm{t}, J=9.2 \mathrm{~Hz}, 1 \mathrm{H}), 3.77(\mathrm{td}, J=9.9,1.7 \mathrm{~Hz}, 1 \mathrm{H}), 3.59-3.55$ (m, 2H), 3.45 (t, $J=10.1 \mathrm{~Hz}, 1 \mathrm{H}$ ), 3.44 (t, $J=9.9 \mathrm{~Hz}, 1 \mathrm{H}), 3.19$ (s, 3H), 3.18 (s, 3H), 3.16-3.09 (m, 4H), 2.28 (t, J=7.5 Hz, $2 \mathrm{H}), 2.22(\mathrm{td}, J=7.3,2.4 \mathrm{~Hz}, 2 \mathrm{H}), 1.66-1.22(\mathrm{~m}, 34 \mathrm{H}), 0.90(\mathrm{t}, J=7.0 \mathrm{~Hz}, 3 \mathrm{H}), 0.88$ (t, $J=7.0 \mathrm{~Hz}, 3 \mathrm{H})$; ${ }^{13} \mathrm{C}$ NMR $\left(\mathrm{CDCl}_{3}, 125 \mathrm{MHz}\right): \delta$ 173.7, 173.3, 138.7, 138.5, 138.3, 138.2, 138.01, 137.95, 128.48, 128.45 , $128.42,128.36,128.2,128.08,128.07,128.05,128.04,127.98,127.87,127.7,127.6,127.5,97.6,97.5$, 82.2, 81.8, 79.7, 79.6, 79.0, 77.2, 75.8, 75.7, 74.8, 74.1, 74.0, 73.32, 73.26, 71.6, 69.9, 55.2, 54.6, 49.5, 47.4, $34.7,34.19,34.16,33.2,31.8,31.3,29.64,29.60,29.55,29.49,29.2,25.6,25.4,25.3,24.9,22.6,22.3,14.1$, 13.9 (Four carbon signals are overlapping with the signals present at 127-128 ppm, two carbon signals are overlapping with the signals present at 22-34 ppm.); IR (neat): 2926, 1728, 1643, 1072, 737, $698 \mathrm{~cm}^{-1}$; $[\alpha]_{\mathrm{D}}+46.5\left(c \mathrm{0.96}, \mathrm{CH}_{2} \mathrm{Cl}_{2}\right)$; HRMS (FAB+); calcd for $\mathrm{C}_{80} \mathrm{H}_{107} \mathrm{NNaO}_{13}(\mathrm{M}+\mathrm{Na})$ : 1312.7641, found: 1312.7643 .

\section{(12R)-12-Myristoyloxystearyl-bis(methyl-2,3,4-tri- $O$-benzyl-6-deoxy- $\alpha$-D-glucopyranoside)}

amine (13) was prepared from myristic acid and amide $\mathbf{1 0}$ as described for $\mathbf{1 2}$ and obtained in $93 \%$ yield: ${ }^{1} \mathrm{H}$ NMR (CDCl 3 , $\left.500 \mathrm{MHz}\right): \delta$ 7.36-7.21 (m, 30H), 5.01-4.54 (m, 13H), 4.47 (d, J=3.6 Hz, 1H), 4.45 (d, $J=3.6 \mathrm{~Hz}, 1 \mathrm{H}), 4.02-3.99(\mathrm{~m}, 1 \mathrm{H}), 3.96(\mathrm{t}, J=9.3 \mathrm{~Hz}, 1 \mathrm{H}), 3.95$ (t, $J=9.1 \mathrm{~Hz}, 1 \mathrm{H}), 3.77$ (td, $J=9.7,1.7 \mathrm{~Hz}$, 1H), 3.59-3.54 (m, 2H), 3.45 (dd, J=9.6, $3.5 \mathrm{~Hz}, 1 \mathrm{H}), 3.44$ (dd, J=9.6, $3.5 \mathrm{~Hz}, 1 \mathrm{H}$ ), 3.19 (s, 3H), 3.18 (s, $3 \mathrm{H}), 3.17-3.09(\mathrm{~m}, 4 \mathrm{H}), 2.28(\mathrm{t}, J=7.6 \mathrm{~Hz}, 2 \mathrm{H}), 2.22\left(\mathrm{~m}_{\mathrm{c}}, 2 \mathrm{H}\right), 1.64-1.22(\mathrm{~m}, 50 \mathrm{H}), 0.90-0.83(\mathrm{~m}, 6 \mathrm{H})$; ${ }^{13} \mathrm{C} \mathrm{NMR}\left(\mathrm{CDCl}_{3}, 125 \mathrm{MHz}\right): \delta 173.7,173.3,138.7,138.5,138.3,138.2,138.01,137.94,128.5,128.44$, $128.42,128.36,128.2,128.08,128.06,128.05,128.03,127.99,127.9,127.7,127.6,127.5,97.6,97.5,82.2$, 81.8, 79.68, 79.66, 79.6, 79.0, 75.8, 75.7, 74.8, 74.1, 74.0, 73.33, 73.26, 71.6, 69.9, 55.2, 54.6, 49.5, 47.3, $34.7,34.20,34.15,33.2,31.9,31.8,29.69,29.67,29.64,29.61,29.56,29.5,29.34,29.30,29.20,29.19$, 25.6, 25.4, 25.3, 25.2, 22.7, 22.6, 14.11, 14.06 (Four carbon signals are overlapping with the signals 
present at 127-129 ppm, four signals are overlapping with the signals present at 28-30 ppm, and two signals are overlapping at 22.7 ppm.); IR (neat): 2960, 1730, 1651, 1454, 1092, 737, $698 \mathrm{~cm}^{-1} ;[\alpha]_{\mathrm{D}}+37.9$ (c 1.06, $\mathrm{CH}_{2} \mathrm{Cl}_{2}$ ); HRMS (FAB+); calcd for $\mathrm{C}_{88} \mathrm{H}_{123} \mathrm{NNaO}_{13}(\mathrm{M}+\mathrm{Na})$ : 1424.8893, found: 1424.8887 .

General procedure for the hydrogenolysis of compounds 11-13. Synthesis of compounds 2-4. (12R)-12-Acetoxystearyl-bis(methyl-6-deoxy- $\alpha$-D-glucopyranoside) amine (2). To a solution of compound $11(89 \mathrm{mg}, 72 \mu \mathrm{mol})$ in dry $\mathrm{MeOH}(5 \mathrm{~mL})$ were added $\mathrm{Pd} / \mathrm{C}(10 \mathrm{wt} \%, 15 \mathrm{mg})$ and conc. HOAc (5 drops). The suspension was evacuated and refilled with $\mathrm{H}_{2}$ (balloon) three times and then stirred at $\mathrm{rt}$ for 19 h. The mixture was filtered through a small plug of reversed phase silica with Celite ${ }^{\circledR}$ on top to remove the catalyst. It was rinsed with $\mathrm{MeOH}$, toluene was added to the resultant filtrate and the solvents were removed in vacuo. Adding toluene and evaporating was repeated twice to give surfactant 2 in quantitative yield (49.9 mg, $72 \mu \mathrm{mol})$ as a colorless, vitreous solid: ${ }^{1} \mathrm{H}$ NMR (MeOD, $\left.500 \mathrm{MHz}\right): \delta 4.88-4.83(\mathrm{~m}, 1 \mathrm{H})$, $4.66(\mathrm{~d}, J=3.8 \mathrm{~Hz}, 1 \mathrm{H}), 4.63(\mathrm{~d}, J=3.6 \mathrm{~Hz}, 1 \mathrm{H}), 3.99$ (d, J=14.8 Hz, 1H), 3.92 (d, J=13.7 Hz, 1H), 3.76-3.57 (m, 6H), 3.39 (ddd, J=17.4, 9.7, 3.8 Hz, 2H), $3.34(\mathrm{~s}, 3 \mathrm{H}), 3.32(\mathrm{~s}, 3 \mathrm{H}), 3.11(\mathrm{t}, J=9.3 \mathrm{~Hz}, 1 \mathrm{H})$, 3.05 (t, J=9.3 Hz, 1H), 2.50 (dhex, J=31.6, 7.5 Hz, 2H), 2.02 (s, 3H), 1.65-1.30 (m, 28H), 0.90 (t, $J=6.8 \mathrm{~Hz}, 3 \mathrm{H}) ;{ }^{13} \mathrm{C}$ NMR (MeOD, $125 \mathrm{MHz}$ ): $\delta$ 177.2, 172.9, 101.12, 101.09, 75.7, 75.1, 74.6, 73.9, 73.6, $73.4,72.5,71.9,55.52,55.46,51.8,35.22,35.20,34.0,32.9,30.63,30.62,30.6,30.52,30.51,30.2,26.8$, $26.42,26.39,23.6,21.2,14.4$ (One carbon signal is overlapping with the signals present at $71-75 \mathrm{ppm}$, one carbon signal is overlapping with the signals present at 51-55 ppm, and one carbon signal is overlapping with the signals present at 21-35 ppm.); IR (neat): 3390 (br), 2926, 1738, 1604, 1244, $1051 \mathrm{~cm}^{-1} ;[\alpha]_{\mathrm{D}}$ +76.4 ( $c$ 0.50, MeOH); HRMS (FAB+); calcd for $\mathrm{C}_{34} \mathrm{H}_{63} \mathrm{NNaO}_{13}(\mathrm{M}+\mathrm{Na}): 716.4197$, found: 716.4187 .

(R)-12-Hexanoyloxystearyl-bis(methyl-6-deoxy- $\alpha$-D-glucopyranoside) amine (3) was prepared from 12 as described for 2 and obtained in quantitative yield: ${ }^{1} \mathrm{H}$ NMR (MeOD, $500 \mathrm{MHz}$ ): $\delta$ 4.91-4.83 (m, 1H), $4.66(\mathrm{~d}, J=3.8 \mathrm{~Hz}, 1 \mathrm{H}), 4.63(\mathrm{~d}, J=3.8 \mathrm{~Hz}, 1 \mathrm{H}), 3.99(\mathrm{~d}, J=14.7 \mathrm{~Hz}, 1 \mathrm{H}), 3.91(\mathrm{~d}, J=13.8 \mathrm{~Hz}, 1 \mathrm{H})$, 3.78-3.57 (m, 6H), 3.39 (ddd, J=17.7, 9.7, 3.8 Hz, 2H), $3.34(\mathrm{~s}, 3 \mathrm{H}), 3.32(\mathrm{~s}, 3 \mathrm{H}), 3.11(\mathrm{t}, J=9.3 \mathrm{~Hz}, 1 \mathrm{H})$, 3.04 (t, $J=9.3 \mathrm{~Hz}, 1 \mathrm{H}), 2.50$ (dhex, $J=32.2,7.5 \mathrm{~Hz}, 2 \mathrm{H}), 2.30$ (t, $J=7.2 \mathrm{~Hz}, 2 \mathrm{H}), 1.65-1.30$ (m, 34H), 0.92 $(\mathrm{t}, J=7.0 \mathrm{~Hz}, 3 \mathrm{H}), 0.90(\mathrm{t}, J=7.1 \mathrm{~Hz}, 3 \mathrm{H}) ;{ }^{13} \mathrm{C} \mathrm{NMR}(\mathrm{MeOD}, 125 \mathrm{MHz}): \delta 177.2,175.5,101.2,101.1$, $75.4,75.1,74.6,73.9,73.7,73.5,72.5,71.9,55.53,55.47,51.9,35.5,35.30,35.28,34.1,32.9,32.5,30.7$, 
$30.6,30.54,30.52,30.2,26.8,26.5,26.4,26.0,23.6,23.4,14.4,14.3$ (One carbon signal is overlapping with the signals present at 71-75 ppm, one carbon signal is overlapping with the signals present at 51-55 ppm, and two carbon signals are overlapping with the signals present at 23-35 ppm.); IR (neat): 3325 (br), 2927, 1732, 1622, $1051 \mathrm{~cm}^{-1} ;[\alpha]_{\mathrm{D}}+83.5$ (c 0.81, MeOH); HRMS (FAB+); calcd for $\mathrm{C}_{38} \mathrm{H}_{71} \mathrm{NNaO}_{13}$ $(\mathrm{M}+\mathrm{Na}):$ 772.4823, found: 772.4823 .

\section{(12R)-12-Myristoyloxystearyl-bis(methyl-6-deoxy- $\alpha$-D-glucopyranoside) amine (4) was} prepared from 13 as described for 2 and obtained in quantitative yield: ${ }^{1} \mathrm{H}$ NMR (MeOD, $400 \mathrm{MHz}$ ): $\delta$ 4.92-4.85 (m, 1H), 4.65 (d, J=3.7 Hz, 1H), 4.63 (d, J=3.9 Hz, 1H), 3.99 (d, J=14.5 Hz, 1H), 3.91 (d, $J=13.7 \mathrm{~Hz}, 1 \mathrm{H}), 3.77-3.56(\mathrm{~m}, 6 \mathrm{H}), 3.39$ (ddd, $J=14.0,9.8,3.9 \mathrm{~Hz}, 2 \mathrm{H}), 3.34$ (s, 3H), 3.33 (s, 3H), 3.11 (t, $J=9.2 \mathrm{~Hz}, 1 \mathrm{H}), 3.04(\mathrm{t}, J=9.4 \mathrm{~Hz}, 1 \mathrm{H}), 2.50$ (dhex, $J=34.0,7.6 \mathrm{~Hz}, 2 \mathrm{H}), 2.31$ (t, $J=7.3 \mathrm{~Hz}, 2 \mathrm{H}), 1.66-1.30$ (m, 50H), 0.90 (t, J=7.0 Hz, 6H); ${ }^{13} \mathrm{C}$ NMR (MeOD, $\left.125 \mathrm{MHz}\right): \delta 173.7,173.3,138.7,138.5,138.3,138.2$, $138.0,137.9,128.5,128.4,128.42,128.36,128.2,128.07,128.06,128.03,127.98,127.9,127.7,127.6$, $127.5,97.6,97.5,82.2,81.8,79.7,79.6,79.0,75.8,75.7,74.8,74.1,74.0,73.33,73.26,71.6,69.9,55.2$, $54.6,49.5,47.3,34.7,34.20,34.15,33.2,31.9,31.8,29.69,29.66,29.64,29.61,29.56,29.50,29.34,29.30$, 29.20, 29.19, 25.6, 25.4, 25.3, 25.2, 22.7, 22.6, 14.11, 14.06 (Five carbon signals are overlapping with the signals present at 127-129 ppm. Six carbon signals are overlapping with the signals present at 29-30 ppm.); IR (neat): 3344 (br), 2926, 1732, 1620, $1051 \mathrm{~cm}^{-1}$; $[\alpha]_{\mathrm{D}}+75.1$ (c 1.02, MeOH); HRMS (FAB+); calcd for $\mathrm{C}_{46} \mathrm{H}_{87} \mathrm{NNaO}_{13}(\mathrm{M}+\mathrm{Na})$ : 884.6075, found: 884.6070. 


\section{Determination of CMC}

The CMCs of surfactants 1-3 were determined according to a previously described procedure. ${ }^{20}$ The colored probe Eosin $\mathrm{Y}$ was dissolved in normal saline $(0.9 \% \mathrm{NaCl}$ in water $)$ at a concentration of approximately $15 \mu \mathrm{M}$. A stock solution of each surfactant 1-3 at a concentration of 13-17 $\mathrm{mM}$ was prepared using the Eosin Y solution. Samples for absorbance measurements were prepared by diluting the stock solutions with appropriate amounts of Eosin $\mathrm{Y}$ solution. The absorbance at $\lambda=542 \mathrm{~nm}$ for each sample was determined and plotted versus the surfactant concentration in a semi-logarithmic diagram. The CMC was obtained by fitting a sigmoidal function to the data and calculating the CMC from the fitted function parameters. The CMCs determinations were carried out in ambient temperature $\left(24 \pm 0.5^{\circ} \mathrm{C}\right)$. 


\section{Procedure for measuring the haemolytic activity}

Fresh blood $(20 \mathrm{~mL})$ was collected from adult beagle dogs and carefully centrifuged (10 min at 3000 $\mathrm{rpm})$ to collect the erythrocytes. The plasma was replaced by normal saline $(0.9 \% \mathrm{NaCl}$ in water), and the procedure was repeated three times in total. Surfactants 1-3 were dissolved in normal saline and diluted to typically eight different concentrations. $100 \mu \mathrm{L}$ of each surfactant concentration was added to $400 \mu \mathrm{L}$ of erythrocyte suspension in triplicates. Basal haemolysis was measured by adding $100 \mu \mathrm{L}$ of saline to $400 \mu \mathrm{L}$ of erythrocyte suspension. Immediately after addition of each surfactant concentration the samples were thoroughly mixed and further incubated under gentle shaking at $37{ }^{\circ} \mathrm{C}$ for $40 \mathrm{~min}$. After incubation the erythrocytes were separated by centrifugation ( $6 \mathrm{~min}$ at $3000 \mathrm{rpm}$ ) at $5{ }^{\circ} \mathrm{C}$. The supernatant was recovered for analysis. Total haemolysis was obtained by adding $400 \mu \mathrm{L}$ erythrocyte suspension to $199.6 \mathrm{~g}$ of deionized $\mathrm{H}_{2} \mathrm{O}$, stirring and leaving the mixture for $75 \mathrm{~min}$ at $\mathrm{rt}$. The concentration of released haemoglobin was determined using a spectrophotometric method. ${ }^{38}$ The degree haemolysis $(\% H)$ was calculated according to the equation

$$
\% H=\frac{H b-H b_{0}}{H b_{t o t}} \times 100
$$

where $H b$ is the concentration haemoglobin in each sample, $H b_{0}$ the concentration haemoglobin released from basal haemolysis and $H b_{t o t}$ the amount of haemoglobin released from total haemolysis. $\% H$ was plotted as a function of surfactant concentration in the erythrocyte samples.

The study was approved by the Animal Ethics Committee of Gothenburg, ethics approval number 120200. 


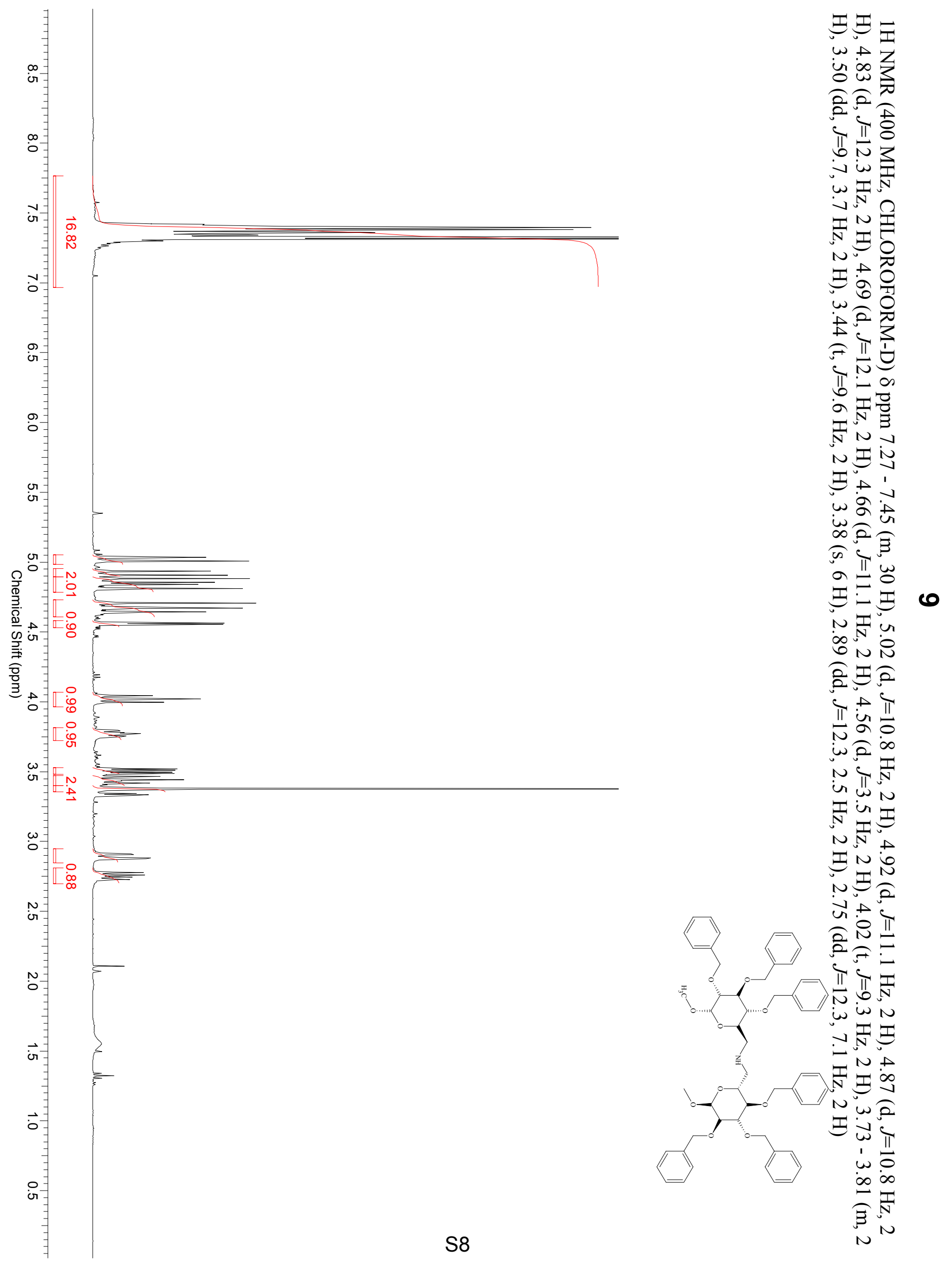



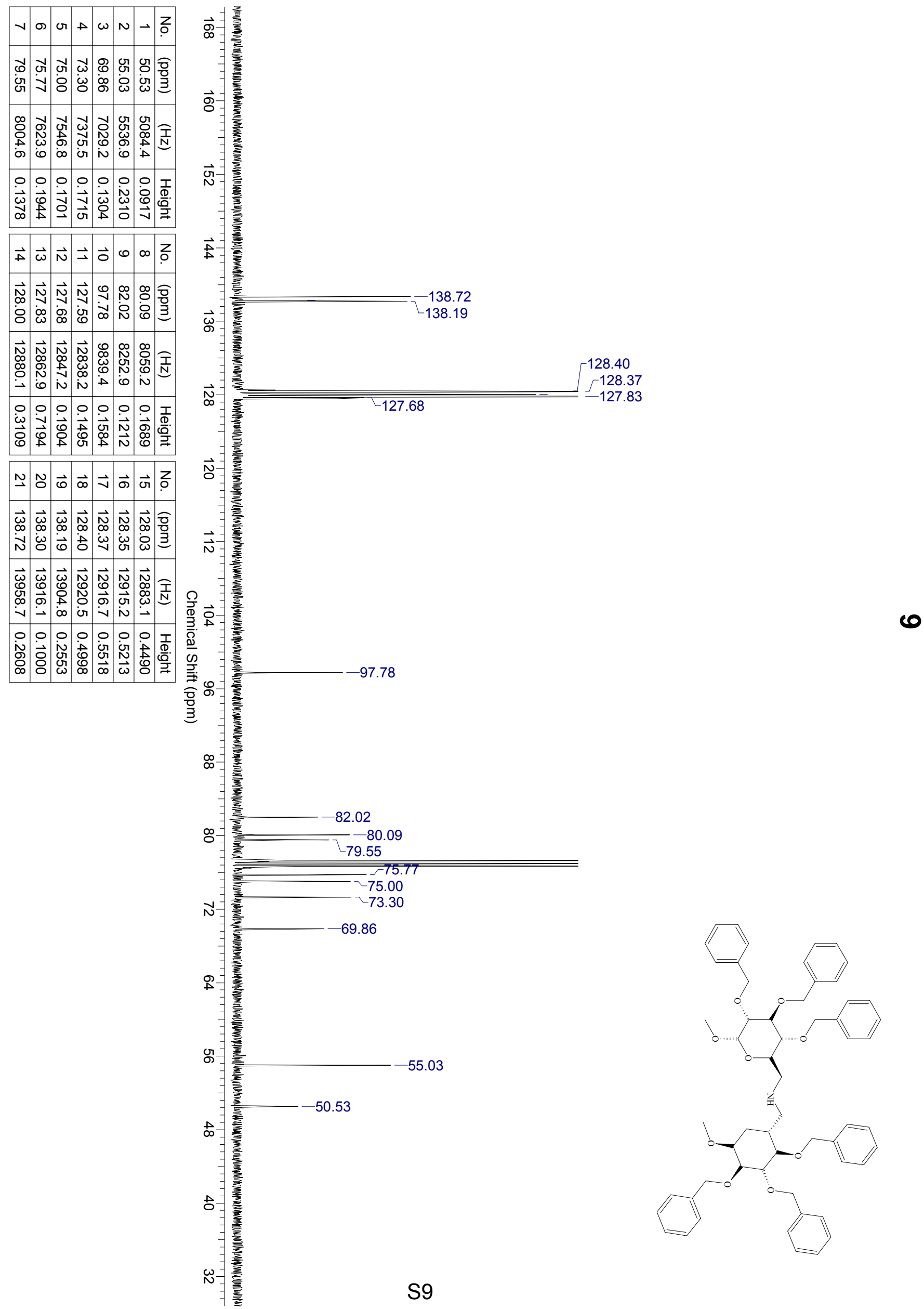


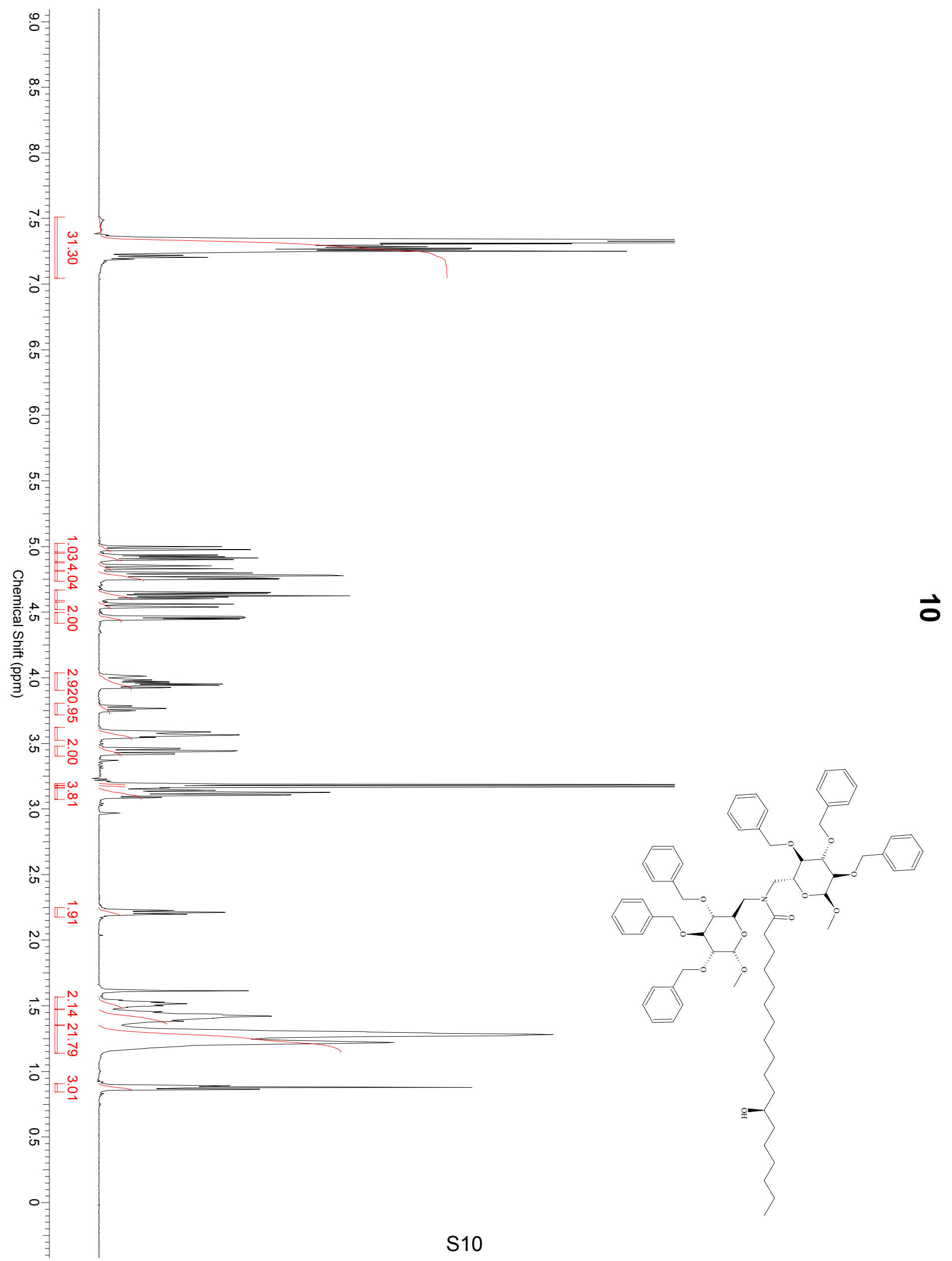




\begin{tabular}{|c|c|c|c|c|c|c|c|c|c|c|c|c|}
\hline$\vec{\perp}$ & $\vec{\omega}$ & & & & 0 & & $\sigma$ & o & $A$ & $\omega$ & $N$ & ○ \\
\hline 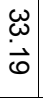 & \begin{tabular}{|c}
$\omega$ \\
$\dot{\omega}$ \\
$\dot{f}$
\end{tabular} & & đ़ै & & b & $\begin{array}{lll}0 \\
s \\
s\end{array}$ & v & & $\begin{array}{l}\tilde{N} \\
\tilde{G} \\
\stackrel{\rightarrow}{-}\end{array}$ & & $\begin{array}{l}N \\
\\
0 \\
0\end{array}$ & $\begin{array}{l}\overrightarrow{4} \\
\dot{0}\end{array}$ \\
\hline & $\mid \begin{array}{l}\overrightarrow{0} \\
\dot{0} \\
+ \\
0\end{array}$ & & & & tu & & & & & $\underset{\sim}{\sim}$ & & 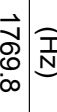 \\
\hline & $\begin{array}{l}0 \\
\dot{0} \\
\vec{\sigma} \\
\overrightarrow{0}\end{array}$ & & 0 & & & P & & & & & & 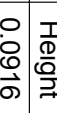 \\
\hline
\end{tabular}

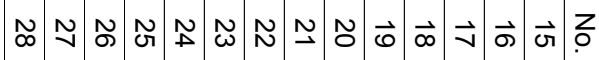
जै जै

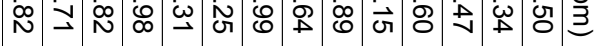

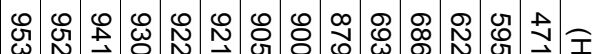

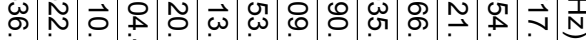

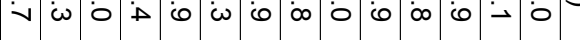

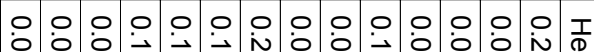

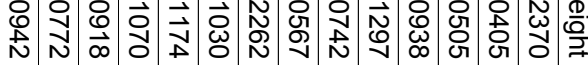

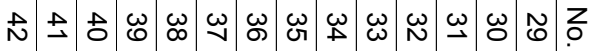

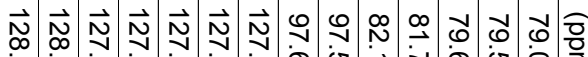

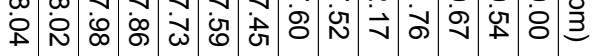

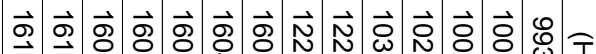

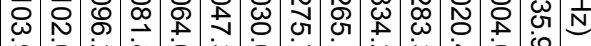
$\dot{0} 0$ N

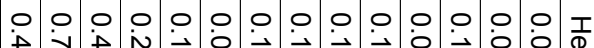

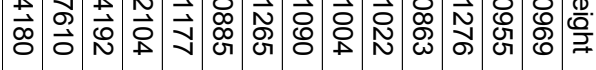

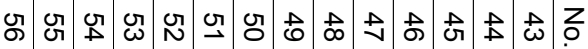

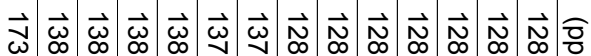
峞 $\vec{v} \vec{\sim} \overrightarrow{\vec{\omega}} \vec{\omega} \vec{\omega} \vec{\omega} \vec{\omega} \vec{\sigma} \vec{\sigma} \vec{\sigma} \vec{\sigma} \vec{\sigma} \vec{\sigma} \vec{\sigma}$

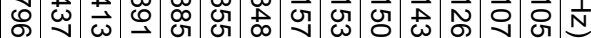

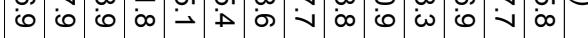

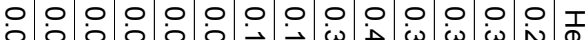

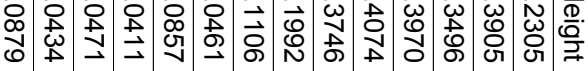

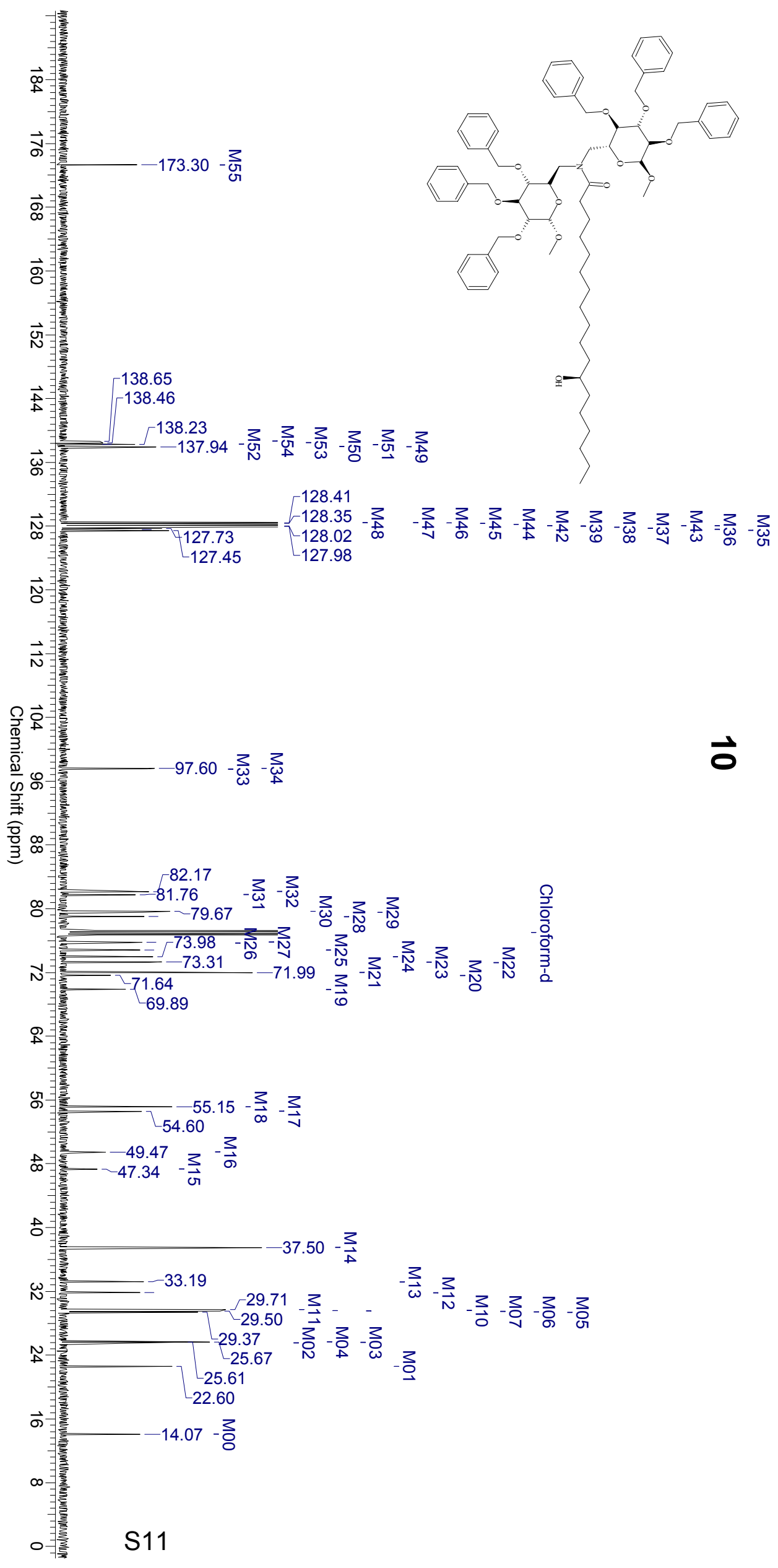




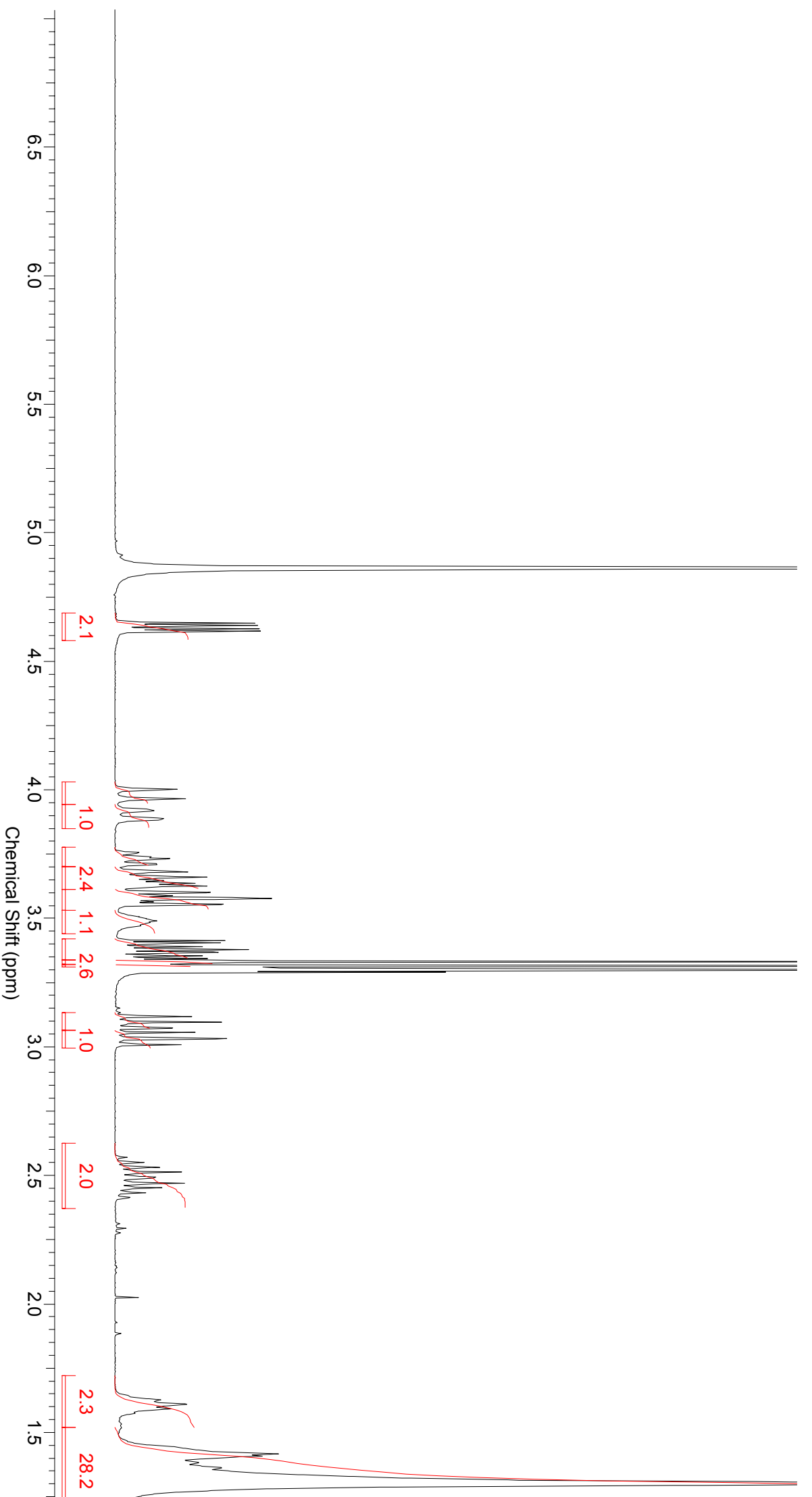

思岂焉

可高夏

岕氙韋

의

介欲

617

w

空通

중

t?

$N$

更

0 w

1 in

N

D i

$\infty \omega \pi$

F金㶽

N合

$\Xi \mathrm{N}$

N

的氙

u $w$.

1 该

w

बें

实出

$N \stackrel{\infty}{\infty}$

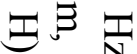

-

的志

$\sigma \mathrm{w}$

1 in

to

文的

N以

F

응

今

En

OI

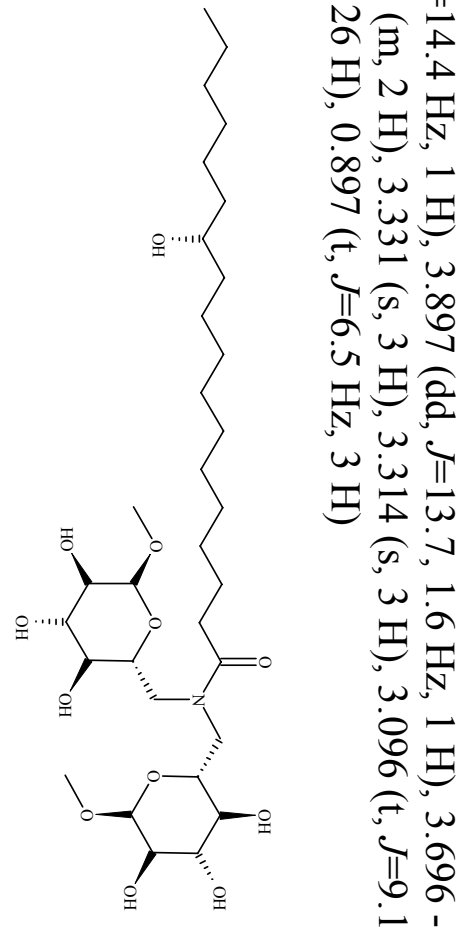



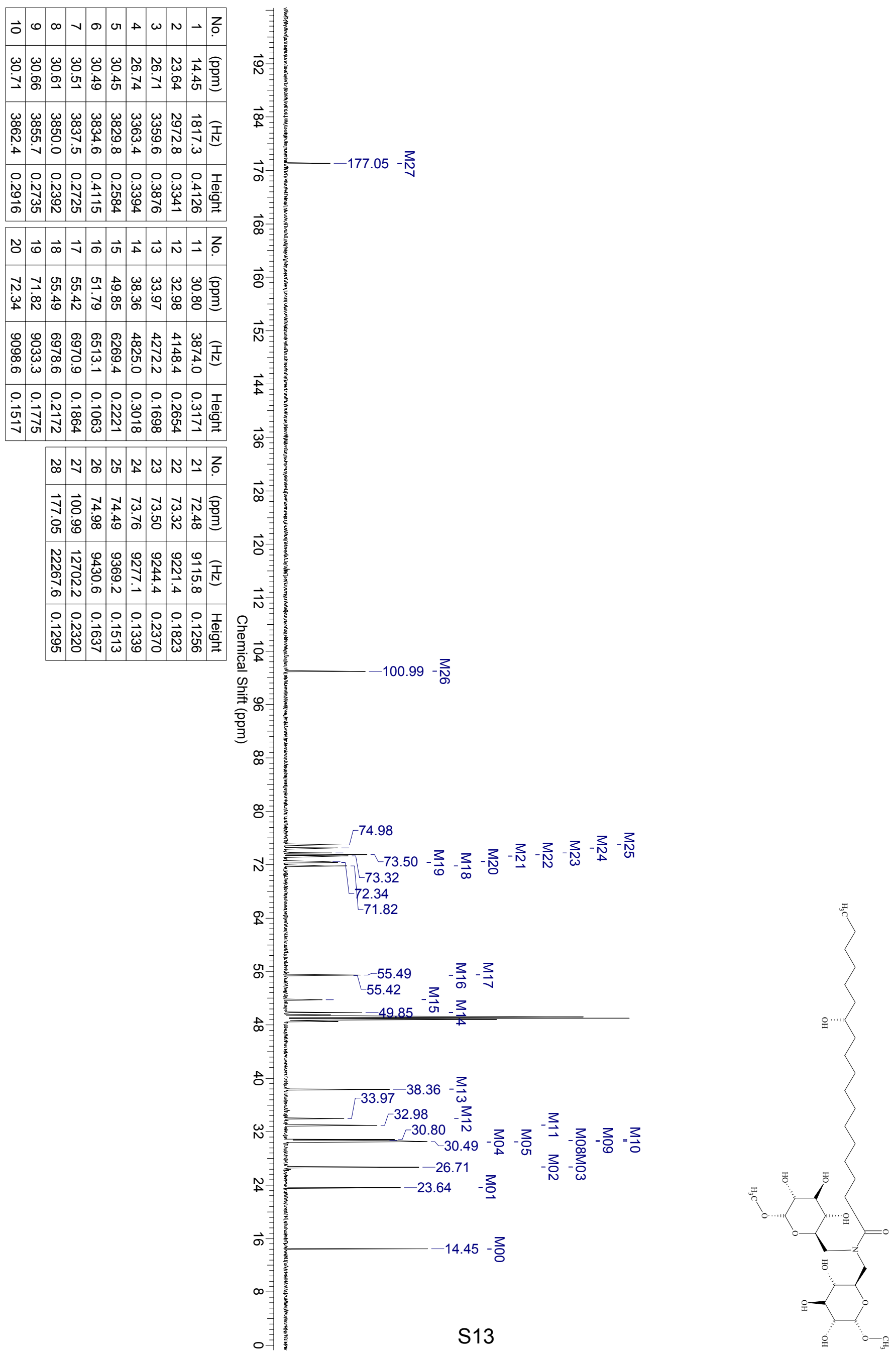


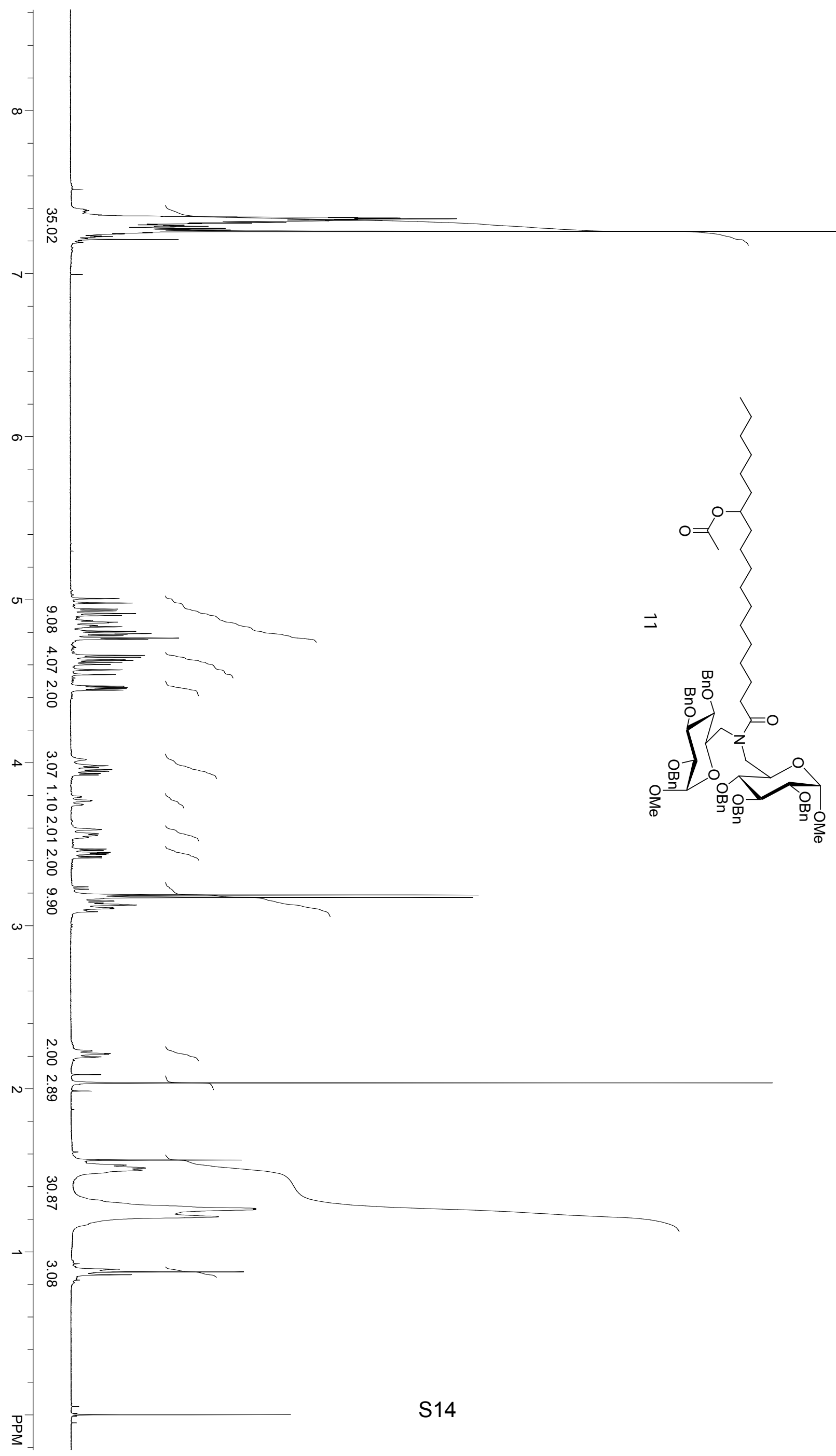




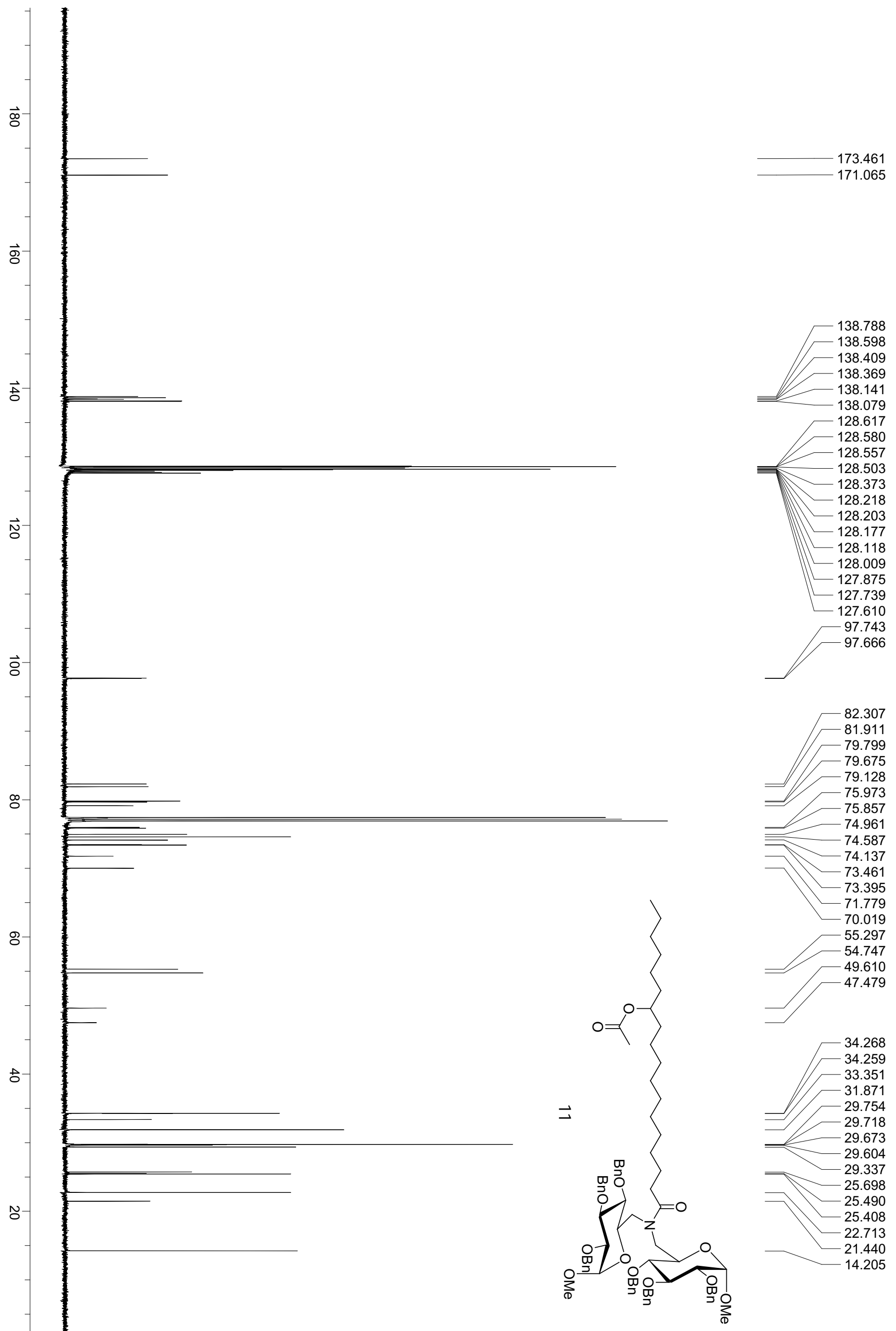




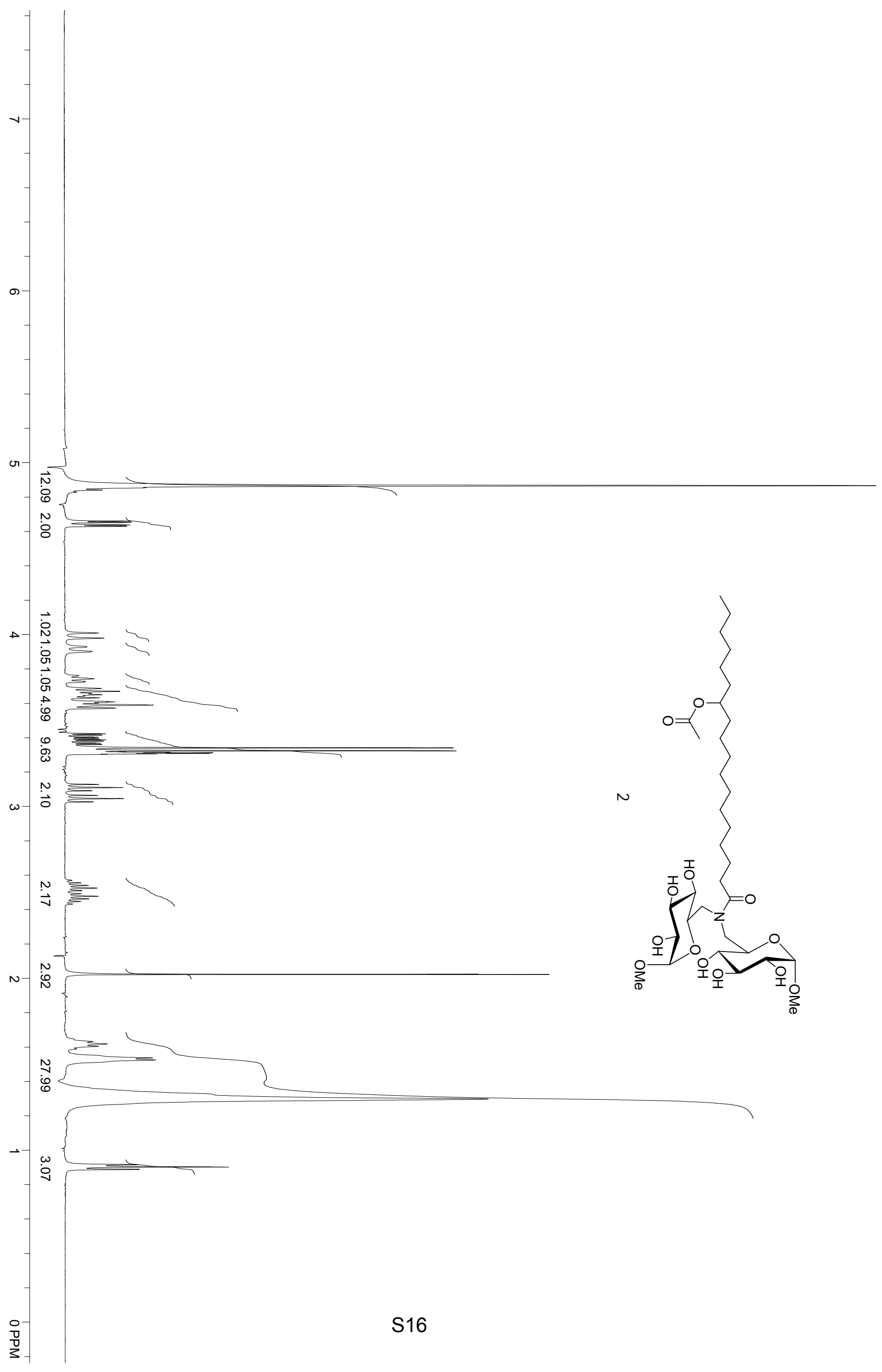



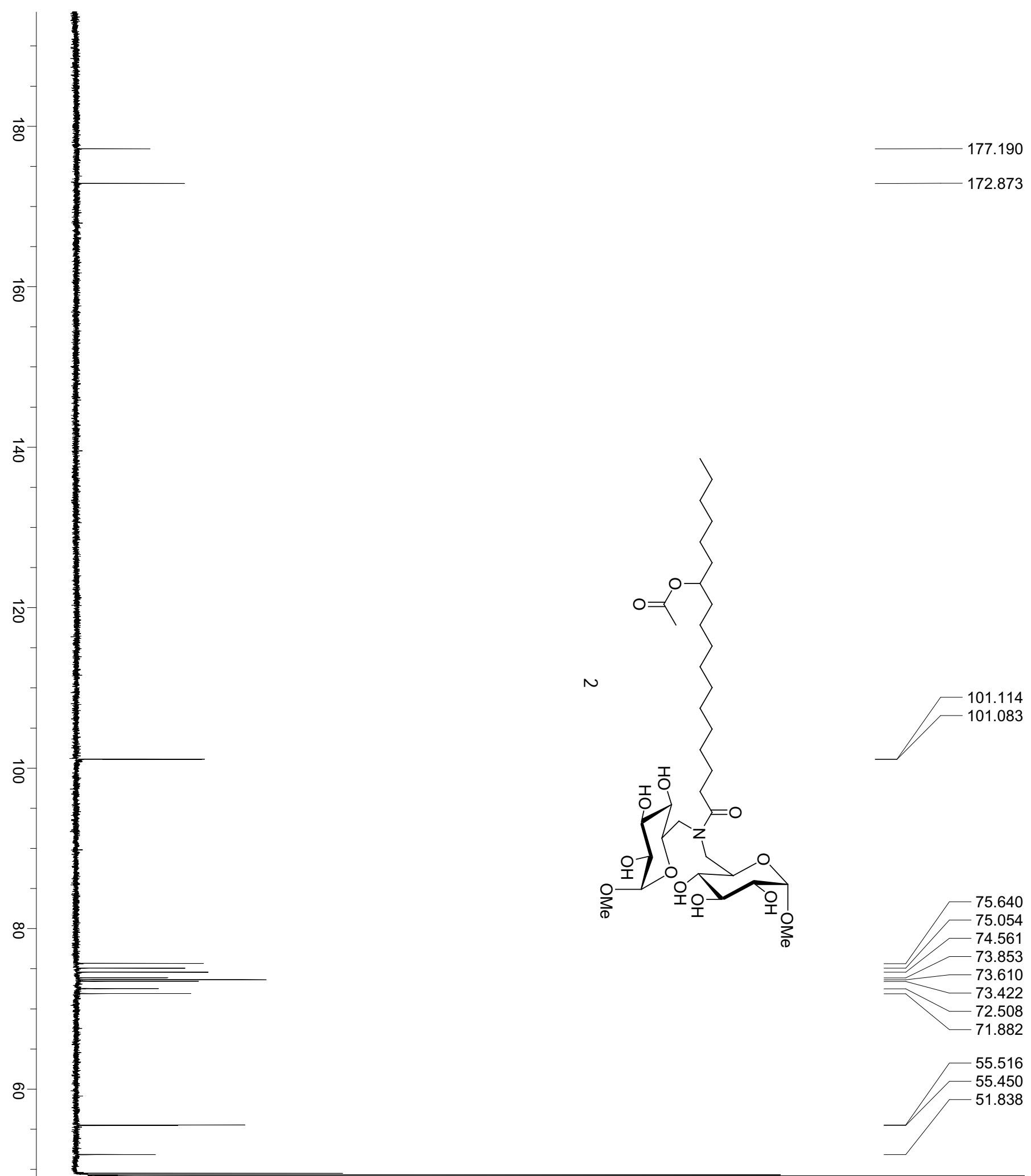

D
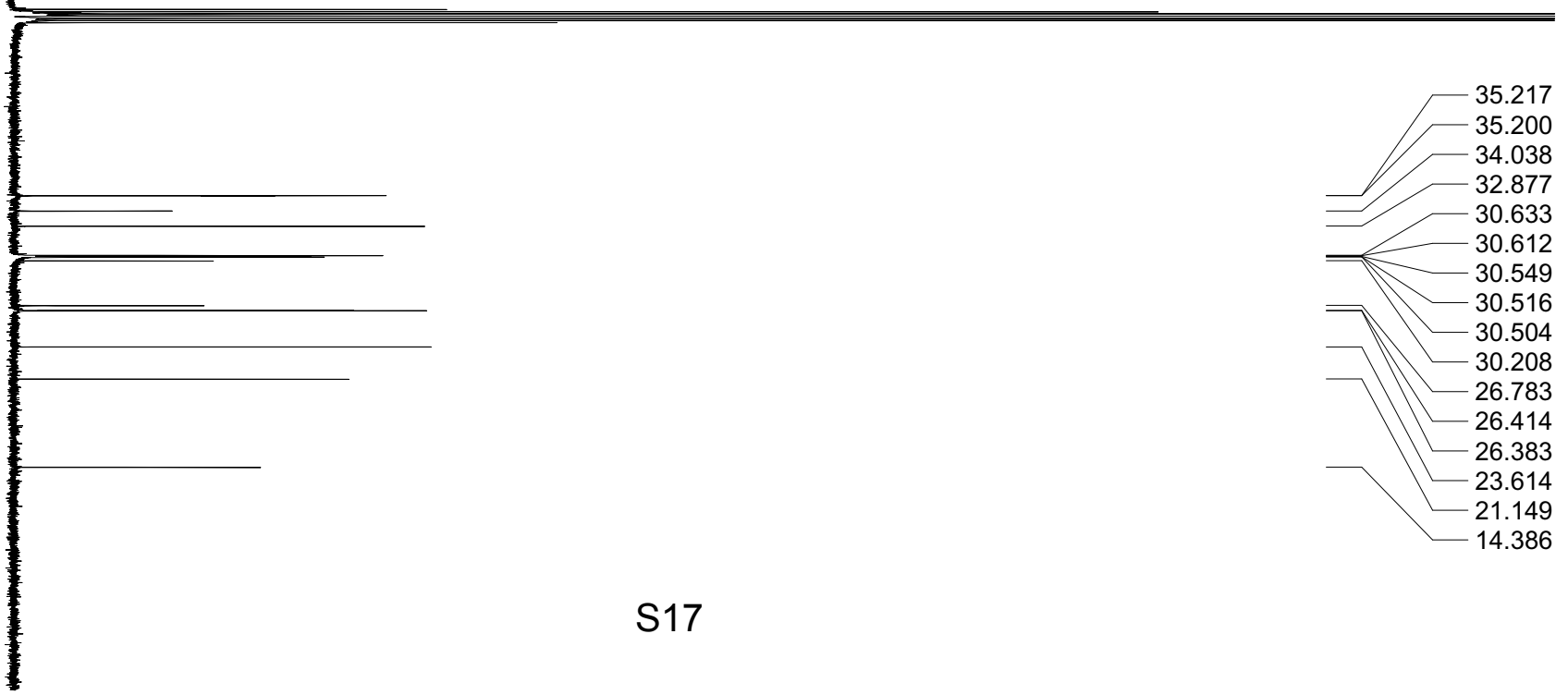


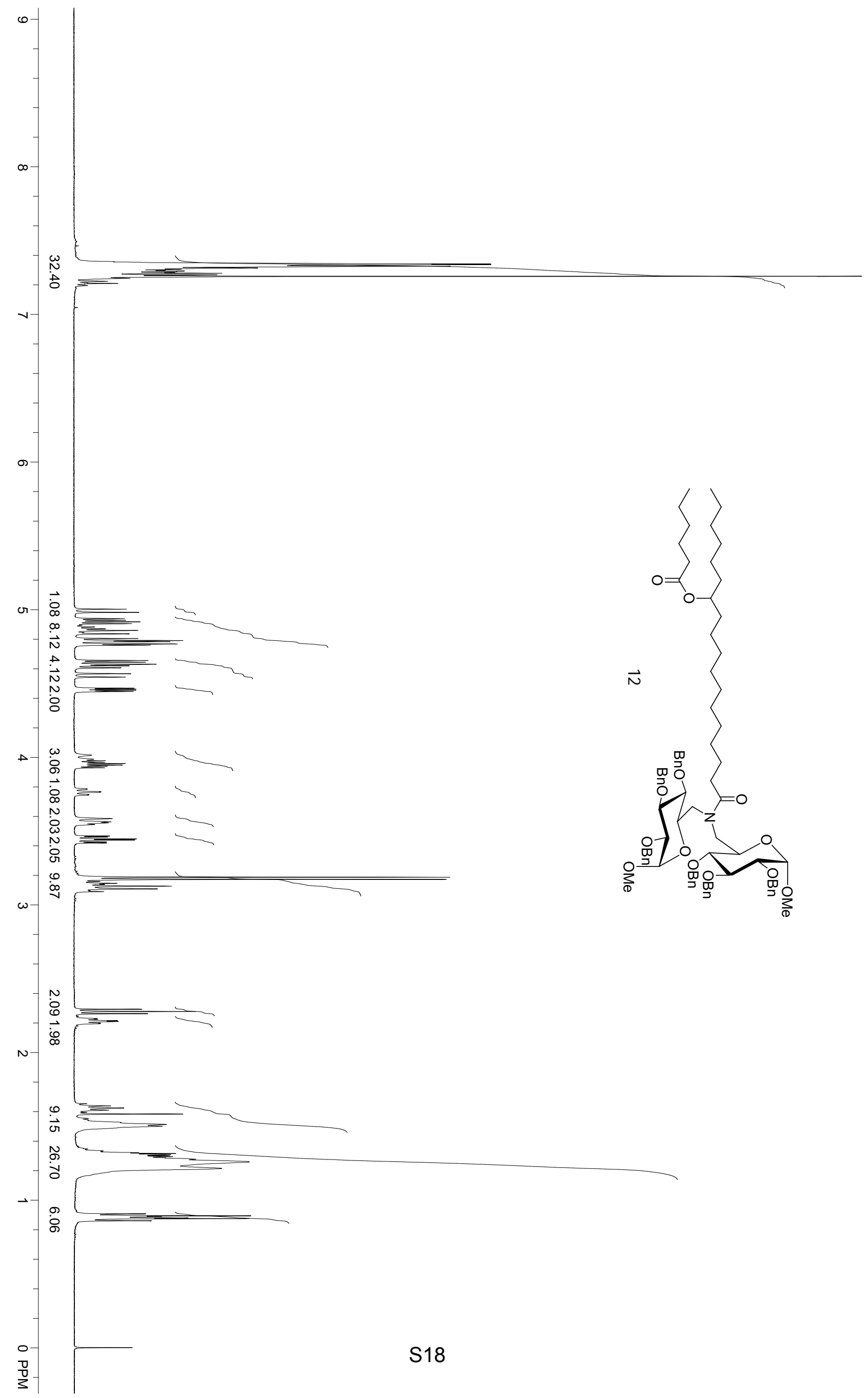




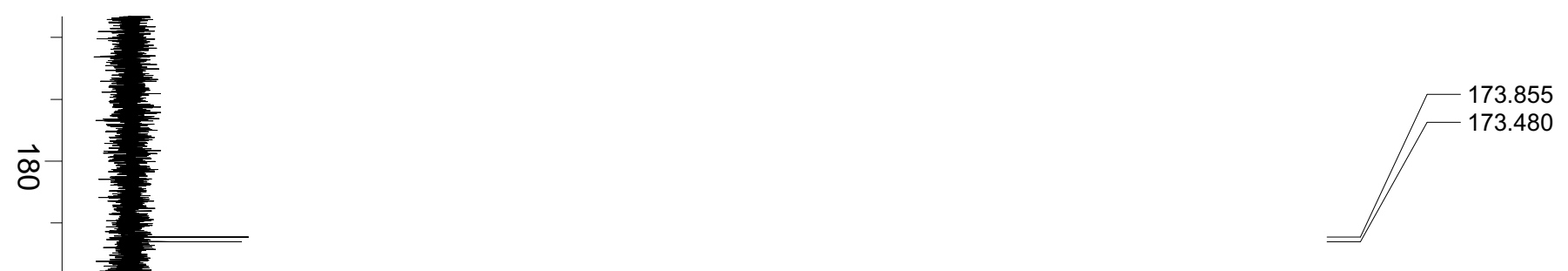

함

$\overrightarrow{\text { D }}$

$\vec{N}$
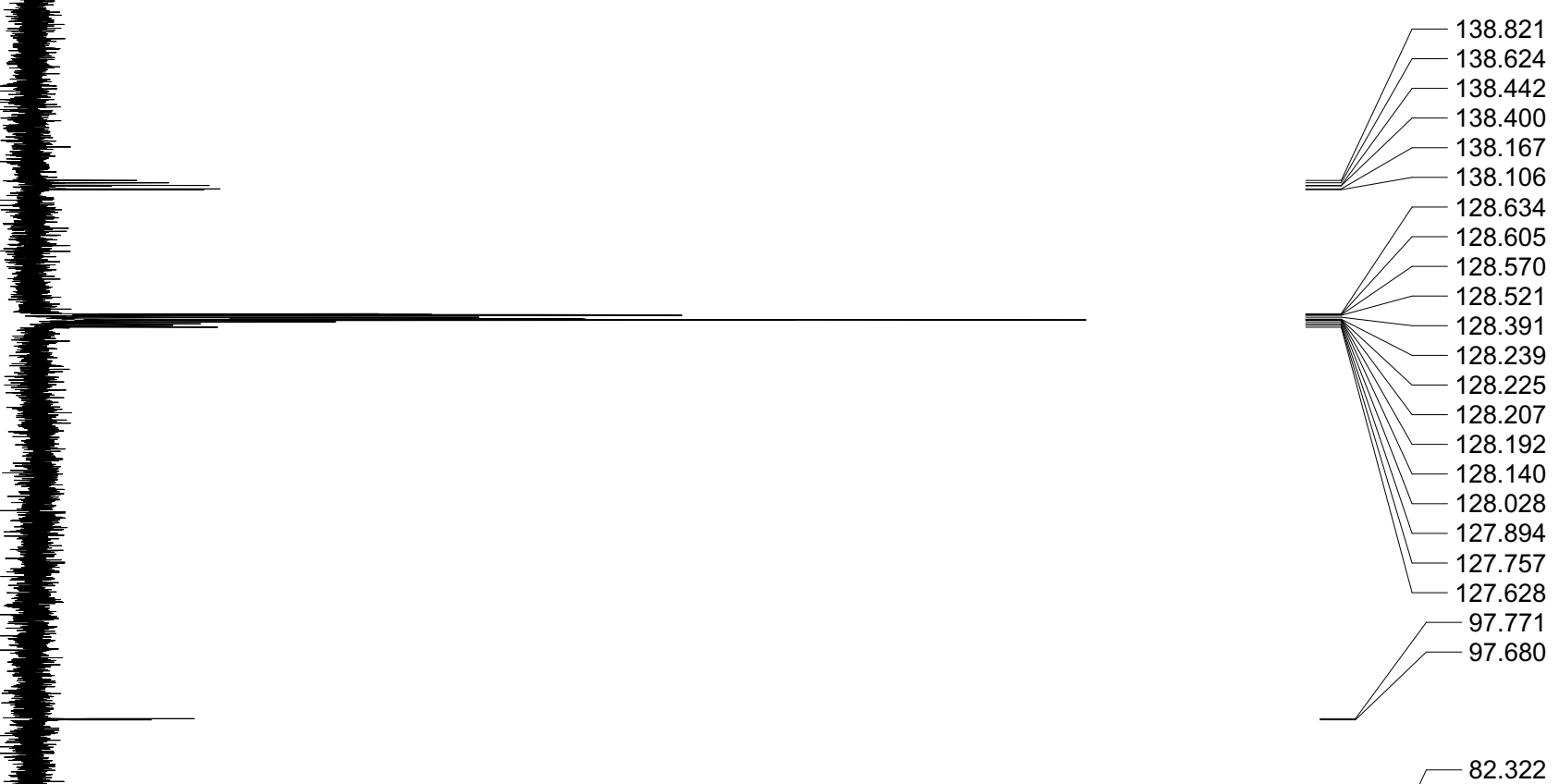

81.930

79.839

$-79.712$

$-79.164$

$-77.364$

- -75.994

75.875

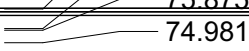

$\equiv \quad 74.981$

74.231
-74.149

73.482

-73.482
-71.792
-71.041

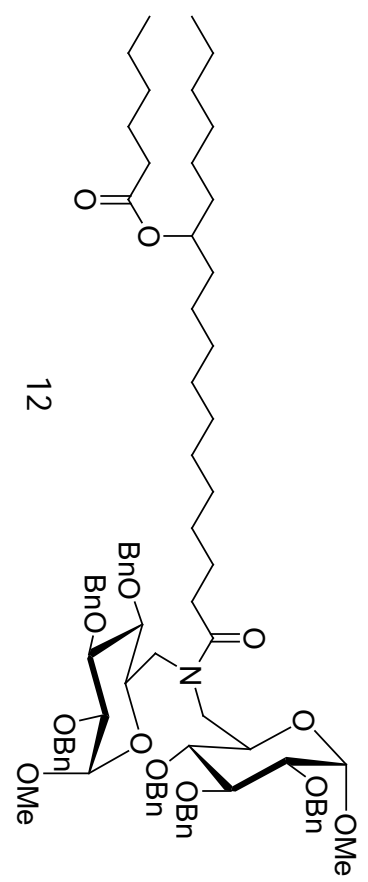

70.041

55.315

54.765

$-\quad-49.638$

$-47.505$

N-1

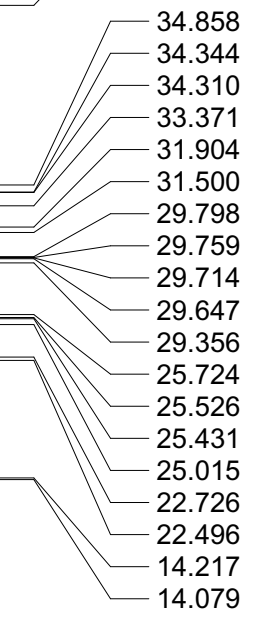




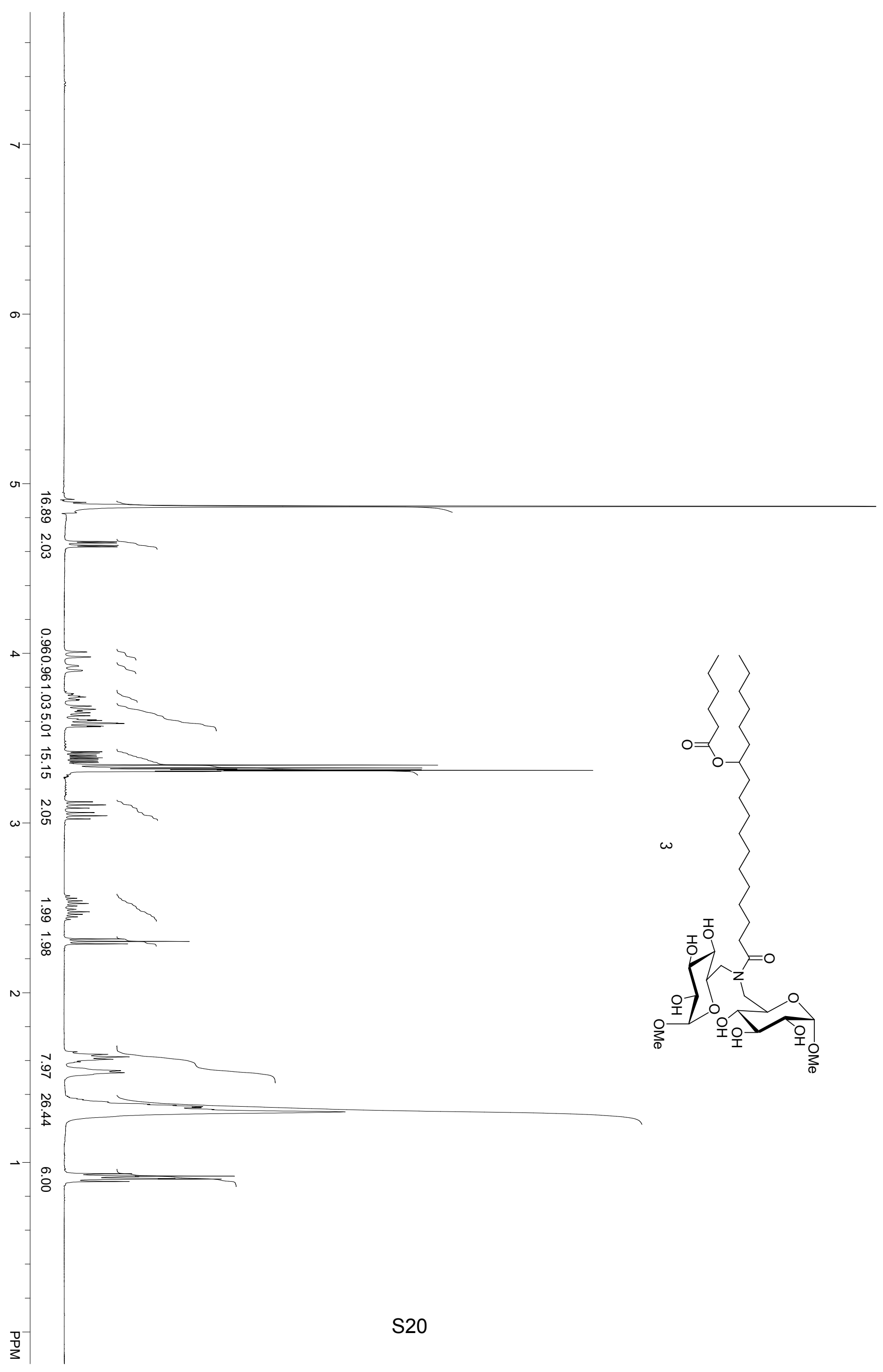



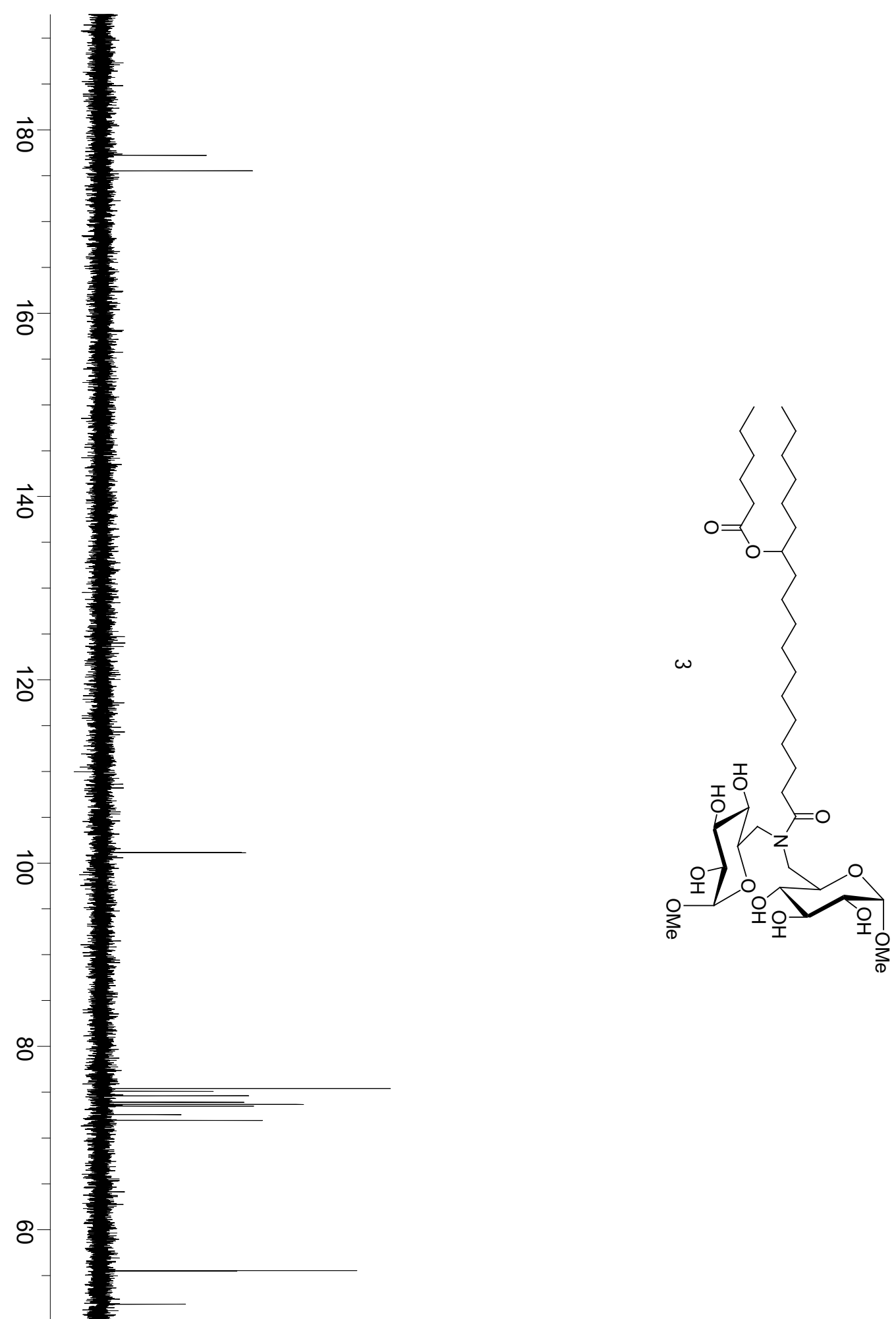

55.525 


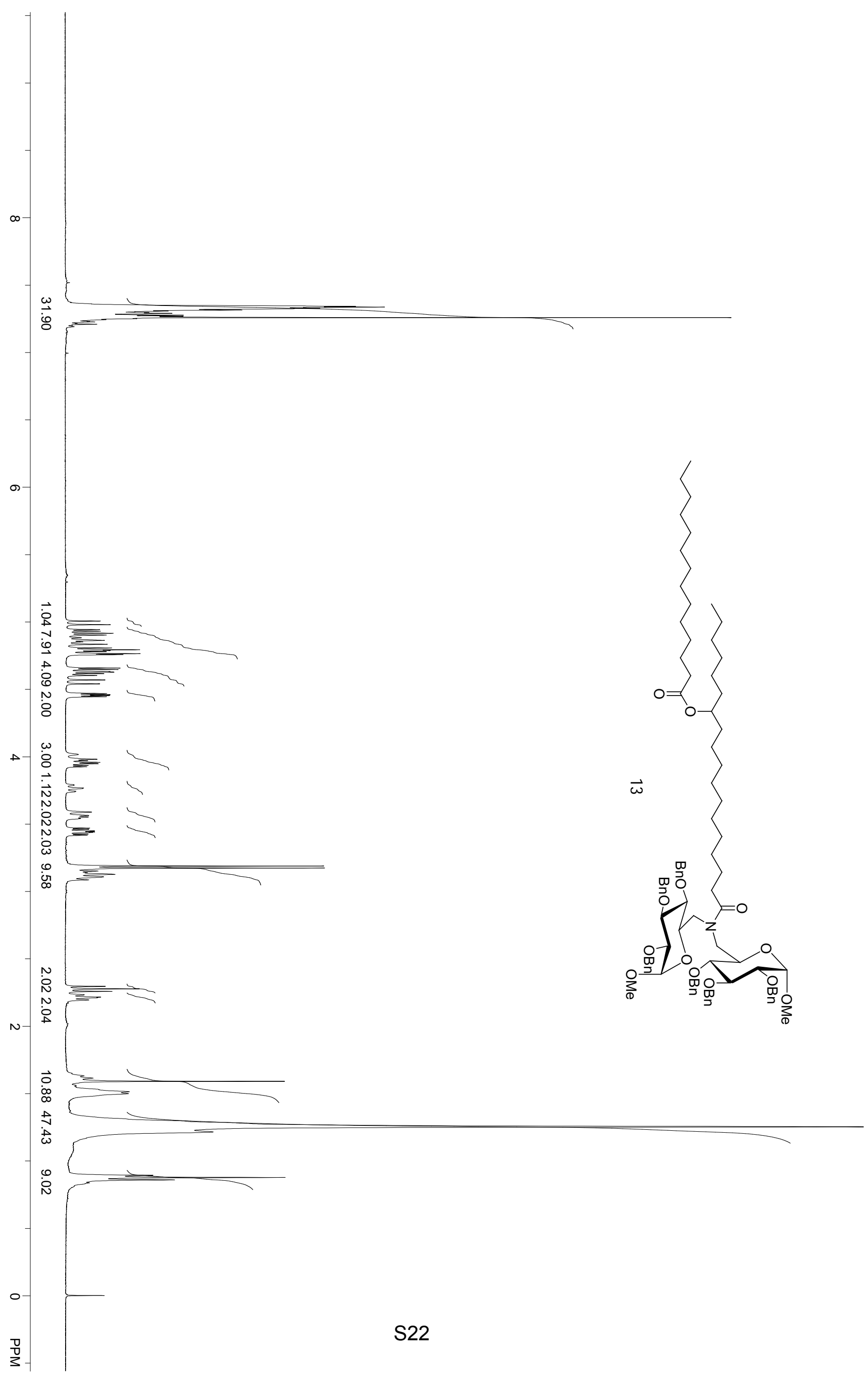




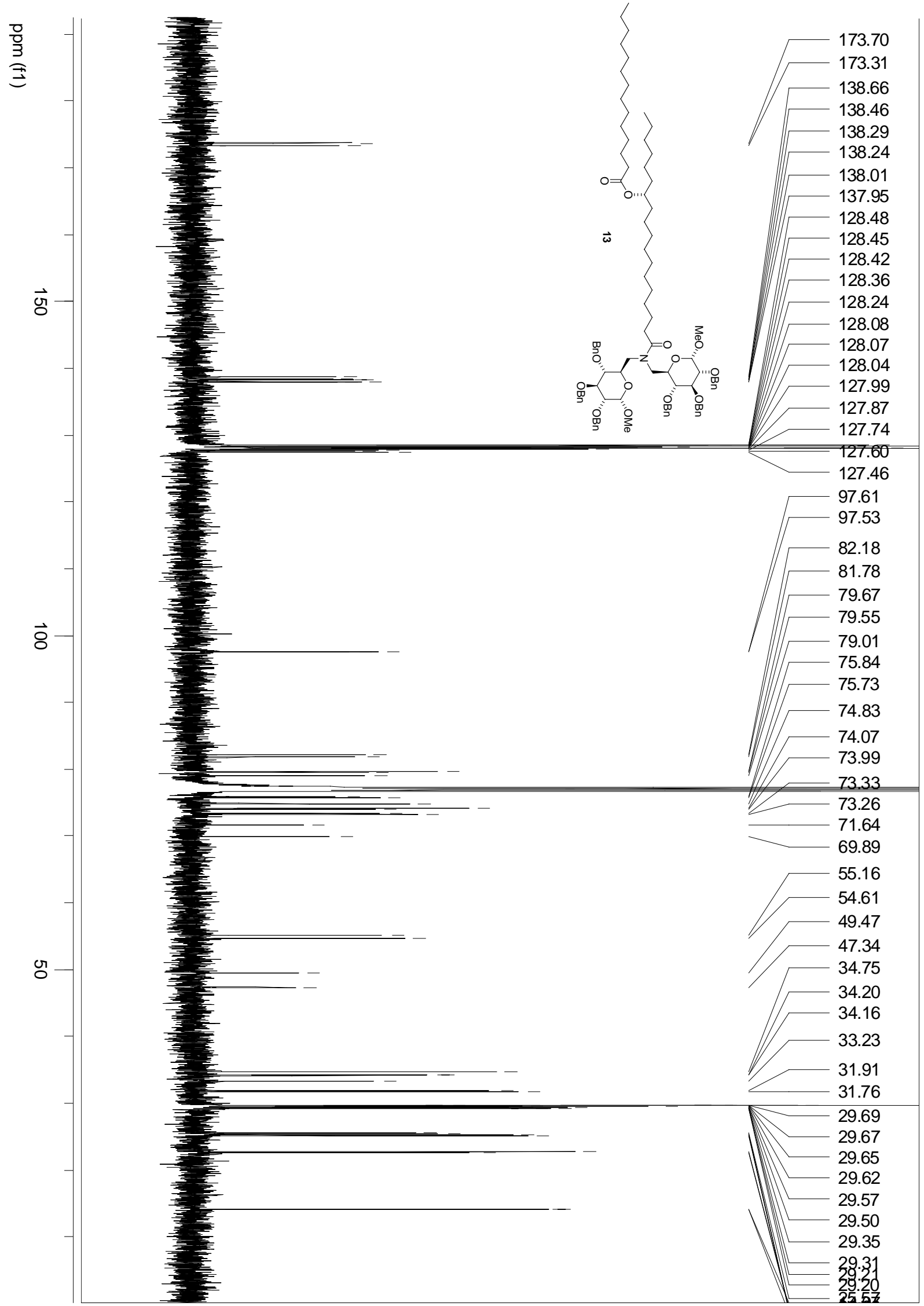




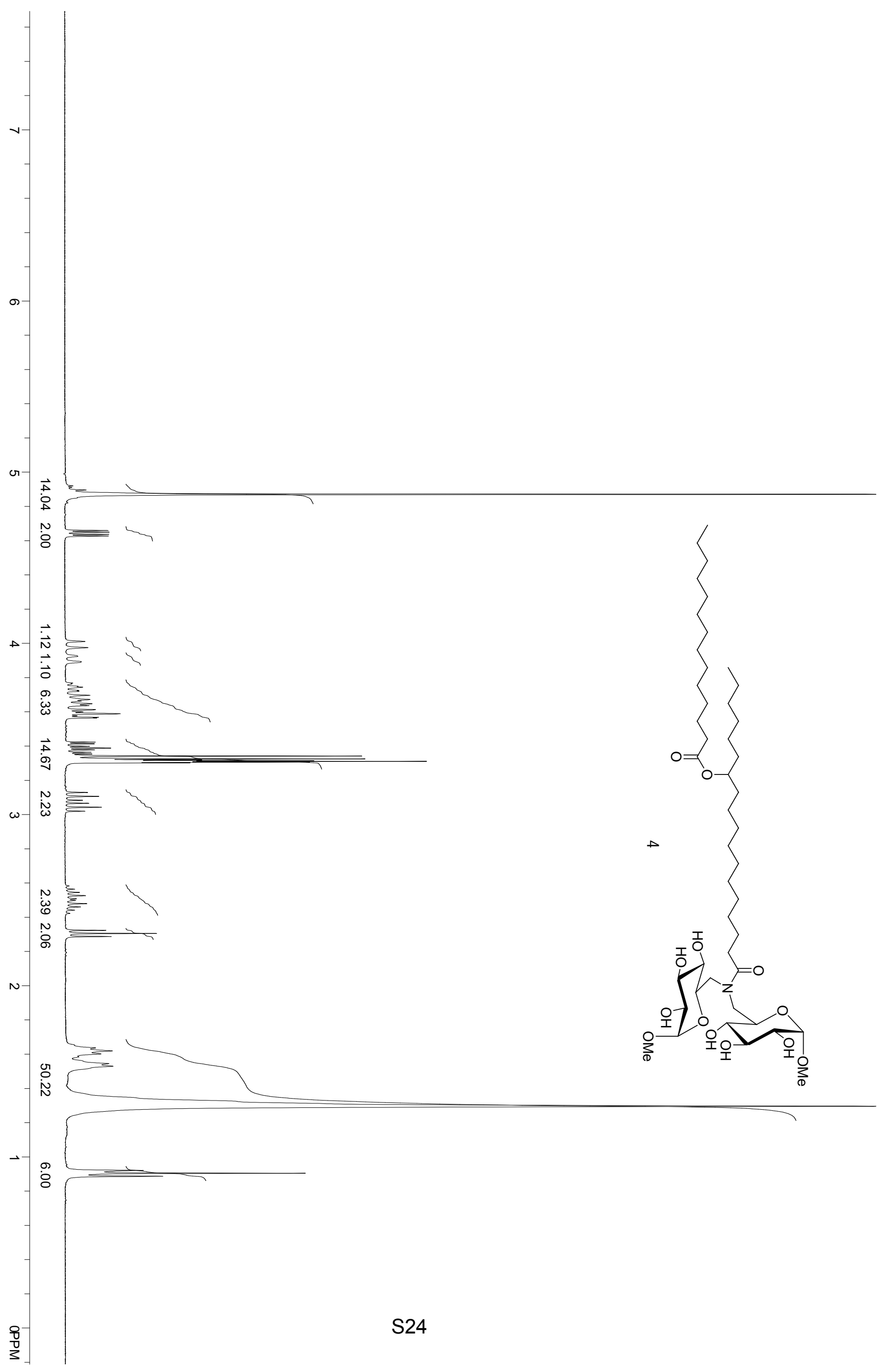



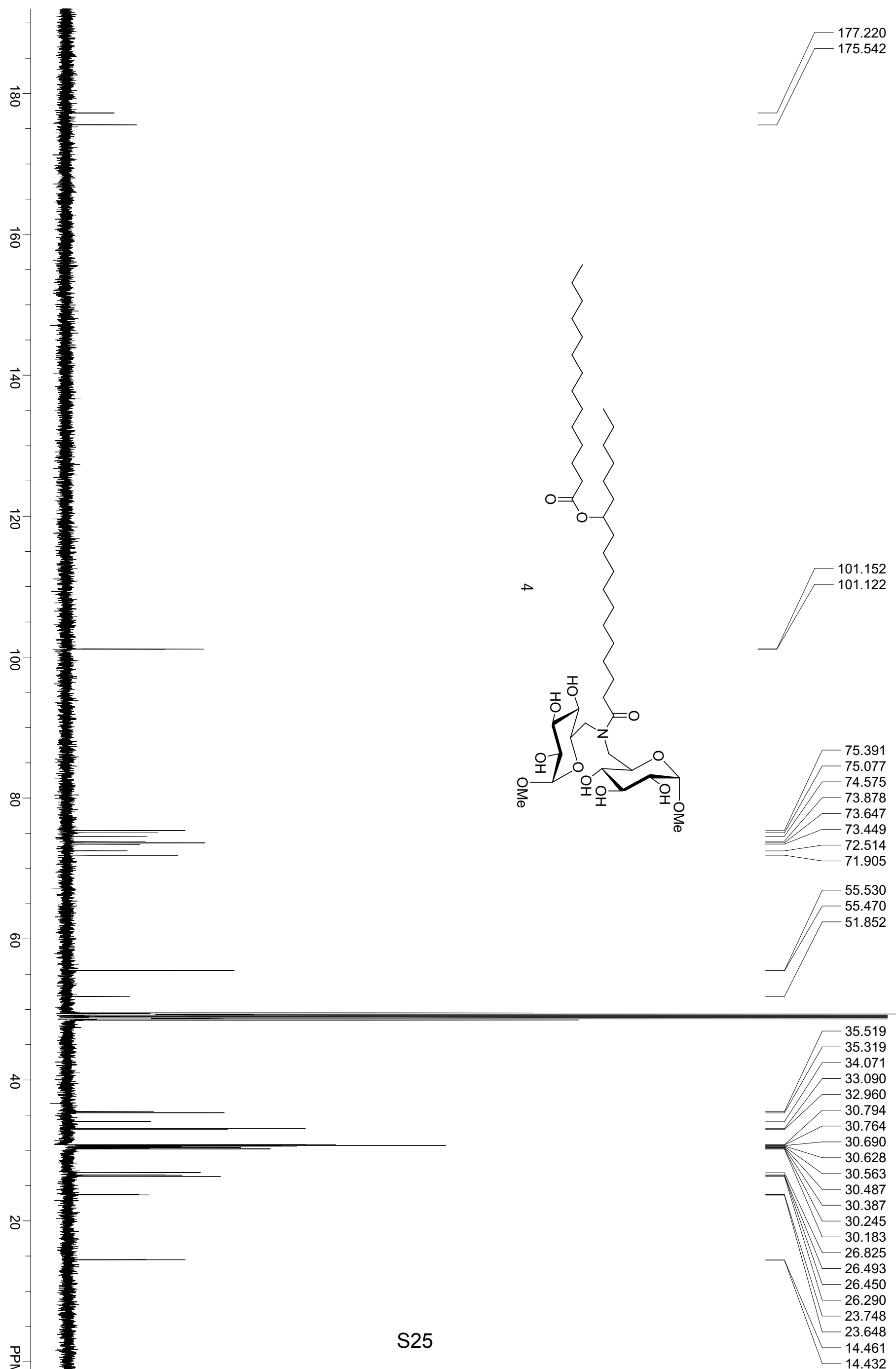